\title{
METHOD FOR HEAT TREATMENT OF THE RUNNING SURFACE OF THE HEAD OF THE PEARLITIC STEEL RAILS
}

\section{METODA OBRÓBKI CIEPLNEJ WARSTWY TOCZNEJ SZYN PERLITYCZNYCH}

The paper deals with the new approach to the optimization of the pearlitic rail's head hardening process aimed at balancing the relation between strength and ductility of the head running surface. In the industrial process, efforts have been undertaken so far to maximize the hardness of the rail's head while maintaining its pearlite structure, resulting in obtaining enhanced wear resistance and resistance to the contact fatigue defects initiation. The new approach, described in this paper, aims at designing the head hardening process enabling achievement of the high hardness of the running surface combined with high ductility expressed in terms of the total elongation. To achieve this aim of the investigation, a computer program was developed capable of predicting the occurrence of the phase transformations during rail head cooling and microstructure features after cooling. The program was linked with dedicated inverse module enabling the adjustment of the cooling conditions to achieve the required state of the pearlitic structure.

Keywords: perlitic rails, heat treatment, mechanical properties, wear, contact fatigue defects

\section{INTRODUCTION}

The pearlitic rail head hardening process has been used for several decades to increase the resistance of the running surface against wear and contact fatigue defects initiation [1, 2]. The most efficient process, so called in line process, is performed directly after rolling and involves controlled - accelerated cooling to obtain fine pearlitic structure, characterized by low cementite interlamellar spacing, in the range of approximately $0.1-0.14 \mu \mathrm{m}$ [3]. The reduction of the cementite interlamellar spacing results in the strength and hardness increase of the pearlitic structure, which is directly connected with the wear resistance of the rail's head running surface. The accelerated cooling
$W$ artykule przedstawiono nowe podejście do optymalizacji procesu obróbki cieplnej szyn perlitycznych, którego celem jest uzyskanie korzystnej relacji między twardościa a ciagliwościa warstwy tocznej główki szyn. Opracowane dotychczas technologie obróbki cieplnej szyn perlitycznych stawiaty sobie za cel uzyskanie jak najwyższej twardości powierzchni tocznej główki, przy zachowaniu struktury perlitycznej tej powierzchni. Dzięki temu uzyskuje sie znaczacy wzrost odporności tej powierzchni na procesy zużycia $i$ inicjowanie wad kontaktowo-zmęczeniowych. Zaproponowana metoda obróbki cieplnej umożliwia uzyskanie bardzo wysokiej twardości powierzchni tocznej, ale równocześnie, pozwala na uzyskanie wysokiej ciagliwości tej warstwy, wyrażonej poprzez wydtużenie do zerwania $w$ statycznej próbie rozciagania. Warunki obróbki cieplnej, spetniajacej powyższe założenia, opracowano stosując dedykowany program komputerowy, który symuluje przemiany fazowe $w$ szynie, z możliwościa przeprowadzenia optymalizacji procesu z zastosowaniem metody obliczeń odwrotnych.

Słowa kluczowe: szyny o strukturze perlitycznej, obróbka cieplna, wtaściwości mechaniczne, zużycie, wady kontaktowo-zmęczeniowe 
ing this concept was described in [4]. To design the cooling paths to achieve this goal a dedicated computer program was develop based on the phase transformation model, equipped with an inverse algorithm allowing the adjustment of the cooling conditions to obtain a required balance between strength and ductility. This methodology can be applied to all cooling media that are used in the head hardening process.

\section{EXPERIMENTS}

The head hardening experiments described in this paper were conducted by rail's head immersion in polymer aqueous solution (20\% of polihartenol) using laboratory equipment developed at Process Simulation Department of Łukasiewicz - IMŻ (Figure 1). The $400 \mathrm{~mm}$ long 60E1 rail made of R260 steel was used for this purpose. The experiment comprised the reheating of the rail in the laboratory furnace at $1050^{\circ} \mathrm{C}$ for $10 \mathrm{~min}$. followed by inserting upside down in the mounting device and subject to cyclic immersion and emersion of the rails head. The times of these stages of cooling were electronically guided.

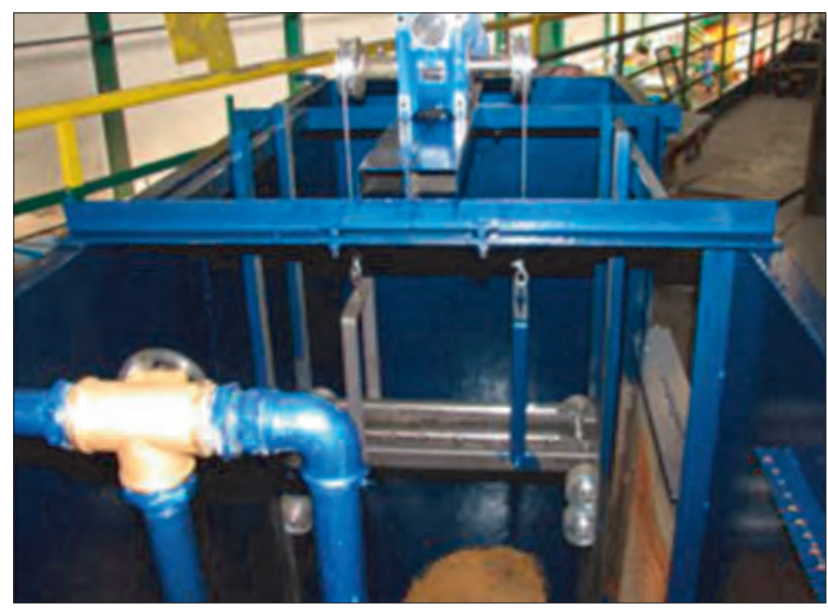

Fig. 1. Equipment for the rail's head hardening process simulation by immersion in polymer aqueous solution

Rys. 1. Urządzenie do symulacji fizycznej obróbki cieplnej szyn metodą zanurzenia $w$ wodnym roztworze mieszanin polimerowych

Following the heat treatment, the samples for mechanical testing and microstructure examination were taken. The tensile test was conducted on Zwick ZWICK Z250. The microstructure of samples taken from the rails subject to heat treatment was analysed with Scanning Electron Microscope Inspect F.

\section{MODEL}

\subsection{THERMAL MODEL}

Calculations of the temperature at the cross section of the rain were performed by the finite element (FE) solution of the heat transfer equation:

$$
\frac{\partial T}{\partial t}=\nabla k \nabla T
$$

where:

$$
\begin{aligned}
& k \text { - conductivity } \\
& T \text { - temperature in absolute scale } \\
& t \text { - time. }
\end{aligned}
$$

The initial condition was obtained from the FE simulation of the rail rolling process, see $[10,11]$. Beyond this, the solution of equation (1) has to satisfy the following boundary condition:

$$
\nabla k T \mathbf{n}=H T C\left(T-T_{n}\right)
$$

where:

n - unit vector normal to the surface

$T_{\mathrm{a}}$ - ambient temperature

$H T C$ - heat transfer coefficient.

HTC was selected depending on the cooling conditions. For air cooling classical radiation equation [12] was used and for cooling in the polymer solution HTC was determined by the inverse solution for the measurements of the temperature. Authors' FE code described in [13], which allowed easy implementation of the phase transformation model, was used to simulate investigated cooling process.

\subsection{PHASE TRANSFORMATION MODEL}

Model of phase transformation was based on the JMAK (Johnson-Mehl-Avrami-Kolmogorov) equation:

$$
X=1-\exp \left(-k t^{\mathrm{n}}\right)
$$

where:

$X$ - volume fraction of a new phase $k, n$ - coefficients.

The numerical implementation of the model (3) is described in [14] and its application to the rail steels is presented in $[11,15]$. The following upgrades were introduced in equation (3) in the present work to adjust it to pearlitic steels:

- Coefficient $n$ was assumed constant (design variables $a_{16}$, and $a_{24}$ for pearlite and bainite transformations, respectively). These coefficients were based on dilatometric tests.

- According to $[14,16]$ coefficient $k$ is temperature-dependent and is described by equations given in Table 1 .

Table 1. Relations describing coefficient $(k)$, incubation times $\left(\tau_{p}, \tau_{b}\right)$ and bainite start temperature $\left(B_{s}\right)$

Tabela 1. Zależności na współczynnik $(k)$, okresy inkubacyjne $\left(\tau_{\mathrm{p}}, \tau_{\mathrm{b}}\right)$ i temperaturę początku przemiany bainitycznej $\left(B_{\mathrm{s}}\right)$

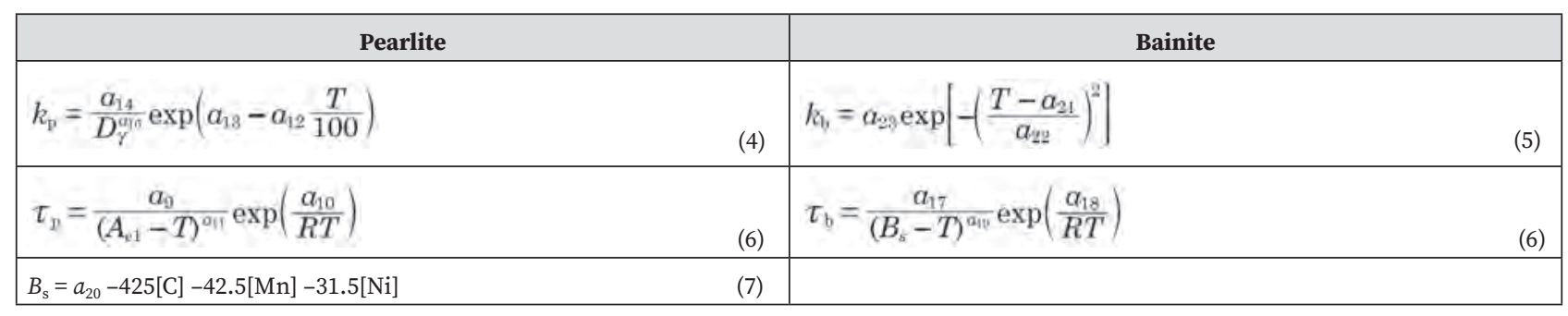


Remaining equations of the model, including incubation times $\left(\tau_{\mathrm{p}}, \tau_{\mathrm{b}}\right)$ and bainite start temperature $\left(B_{\mathrm{s}}\right)$, are given in Table 1. Although bainite should be avoided in the microstructure, the bainitic transformation had to be included in the model, since bainite volume fraction is used as a penalty in the objective function.

Coupled thermal-metallurgical model was validated in [17] by comparison of results with measurements during cooling of rails in the laboratory system described in [2] and very good predictive capability of the model was confirmed. It was also shown in $[15,18]$ that connection of this model with the optimization method allows to design the cooling sequence, which will guarantee obtaining required properties of the rails head. In publication [19] distribution of properties in the rail head was included in the objective function in the optimization procedure.

\subsection{MICROSTRUCTURE AND MECHANICAL PROPERTIES}

Microstructure of the pearlitic steel depends on the average temperature of the pearlitic transformation. This temperature $\left(T_{\mathrm{p}}\right)$ is calculated as a weighted average according to the equation:

where:

$$
T_{\mathrm{p}}=\frac{1}{X} \int_{0}^{X} T d X
$$

$$
X \text { - volume fraction of the pearlite }
$$

$T$ - temperature.

To show how the average temperature of the pearlitic transformation changes depending on the cooling route simulations of various constant cooling rate tests were performed and the results are shown in Figure 2. Pearlite volume fraction is shown in this figure, as well.

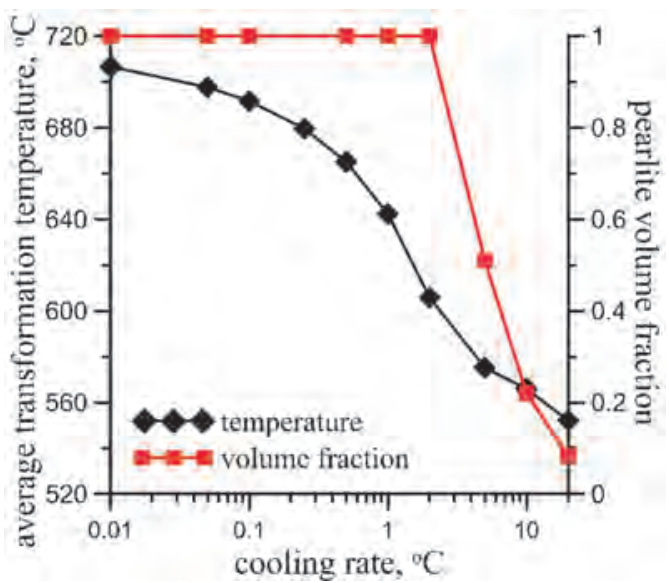

Fig. 2. Effect of the cooling rate on the average temperature of the transformation and on the pearlite volume fraction

Rys. 2. Wpływ szybkości chłodzenia na średnią temperaturę przemiany i udział perlitu

Three parameters describe the microstructure of the pearlitic steels, namely, pearlite grain size $\left(D_{\mathrm{p}}\right)$, pearlite colony size $\left(D_{c}\right)$ and interlamellar spacing $\left(S_{0}\right)$ :

$$
\begin{gathered}
D_{p}=\frac{6500\left[1-\exp \left(-0.016 D_{\gamma}\right)\right]^{0.6}}{A e_{1}-T_{p}} \\
D_{c}=\frac{1}{0.857-0.00119 T_{p}}
\end{gathered}
$$

$$
S_{0}=\frac{1}{a-T_{p}}
$$

Where:

$D_{\gamma}$ - austenite grain size,

$A e 1$ - equilibrium temperature for pearlitic transformation

$T_{\mathrm{p}}$ - pearlite transformation temperature $a, b$ - coefficients

Coefficients in equations(10) and (11) (12) were determined on the basis of experiments described in [20]. Combination of the measurements of the interlamellar spacing with calculated average transformation temperature using equation (9) allowed to determine coefficients in equation (12) as: $a=28.8 ; b=0.0318$ [11].

The mechanical properties of the pearlitic rail steel with fine interlamellar spacing, including yield stress $\left(\sigma_{\mathrm{y}}\right)$ and ultimate tensile strength (UTS), are determined as:

$$
\begin{gathered}
\sigma_{\mathrm{y}}=295.5+114.2 \chi^{-1} \\
U T S=672.5+99.4 \chi^{-1}+72[\mathrm{Si}]
\end{gathered}
$$

Where according to [20] $\chi=\left(2 S_{0}-t\right)$ is the mean free path for dislocation glide in pearlitic ferrite and $t$ is thickness of the cementite plate calculated as $0.015 S_{0}[\mathrm{C}]$.

Since in the current project hardness of the rail head was crucial in optimization procedure, additional tests on the Gleeble 3800 simulator were performed to develop the hardness model. Interlamellar spacing and hardness were measured after each test. Equation describing the hardness of the pearlite $\left(H V_{\mathrm{p}}\right)$ as a function of the interlamellar spacing was obtained by approximation of the results of the measurements [11], as follows:

$$
H V_{\mathrm{p}}=273+\frac{12.2}{S_{0}}
$$

The verification of this model is presented in Figure 3.

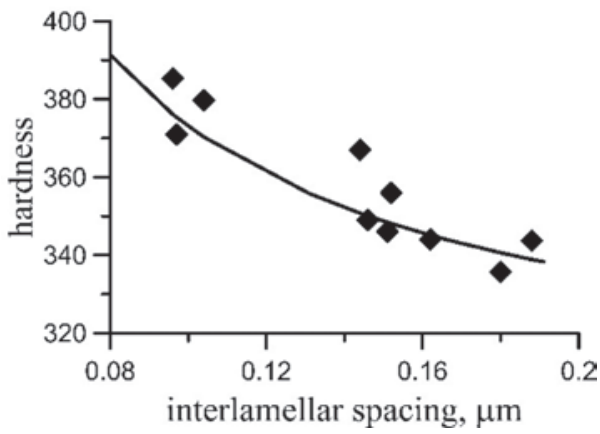

Fig. 3. Hardness measured in the Gleeble tests (filled diamonds) and calculated using equation (14) (line)

Rys. 3. Twardość zmierzona na próbkach poddanych testom w symulatorze Gleeble (punkty) i obliczona za pomocą równania (14) (linia ciagłła)

The whole model describing microstructural parameters and mechanical properties for the pearlitic steels was implemented in the FE code for cooling of rails, and optimization of this process was performed.

\subsection{OPTIMIZATION}

The objective of the numerical modelling was to design the cooling sequence which will allow to obtain high and 
uniform hardness in the rail head and lack of the bainite in the microstructure. Equations in section 4.3 show that the lowest possible average temperature of the pearlitic transformation $\left(T_{\mathrm{p}}\right)$ will result in high hardness. However, lowering this temperature to a value close to $500^{\circ} \mathrm{C}$ results in obtaining low values of elongation to fracture. This feature of the pearlitic transformation is seen in Fig. 1 which shows the dependence of mechanical properties on pearlitic transformation temperature. The isothermal holding of the test samples of R260 steel was carried out in Gleeble 3800 simulator.

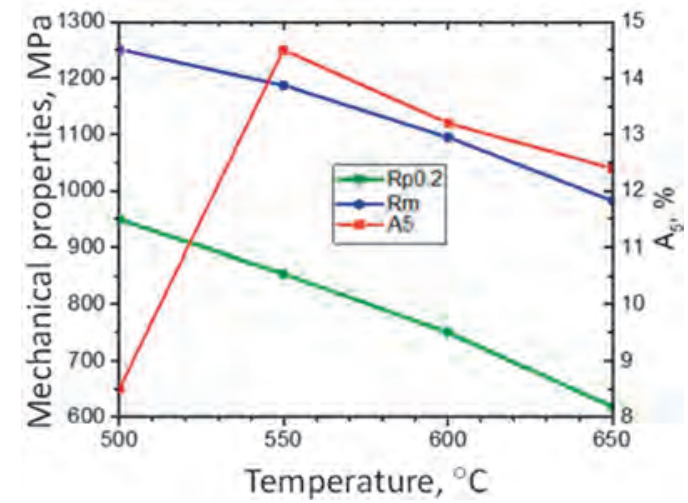

Fig. 4. Dependence of Ultimate Tensile Strength $\left(R_{\mathrm{m}}\right)$, Yield Stress $\left(R_{\mathrm{p} 0.2}\right)$ and Elongation to Fracture $\left(A_{5}\right)$ as function of temperature. Experiments were performed in Gleeble 3800 simulator using samples of R260 steel

Rys. 4. Zależność wytrzymałości na rozciaganie $\left(R_{\mathrm{m}}\right)$, granicy plastyczności $\left(R_{\mathrm{p} 0.2}\right)$ i wydłużenia całkowitego $\left(A_{5}\right)$ od temperatury. Doświadczenia wykonano w symulatorze Gleeble 3800 na próbkach ze stali R260

The dependence of mechanical properties on transformation temperature can be explained in terms of the obtained microstructure of the samples (Figure 5). The microstructure of the sample subject to isothermal holding at $550^{\circ} \mathrm{C}$ consists solely of fine pearlite, whilst that in the sample held at $500^{\circ} \mathrm{C}$ is composed of the mixture of the fine pearlite, degenerate pearlite and upper bainite. The latter

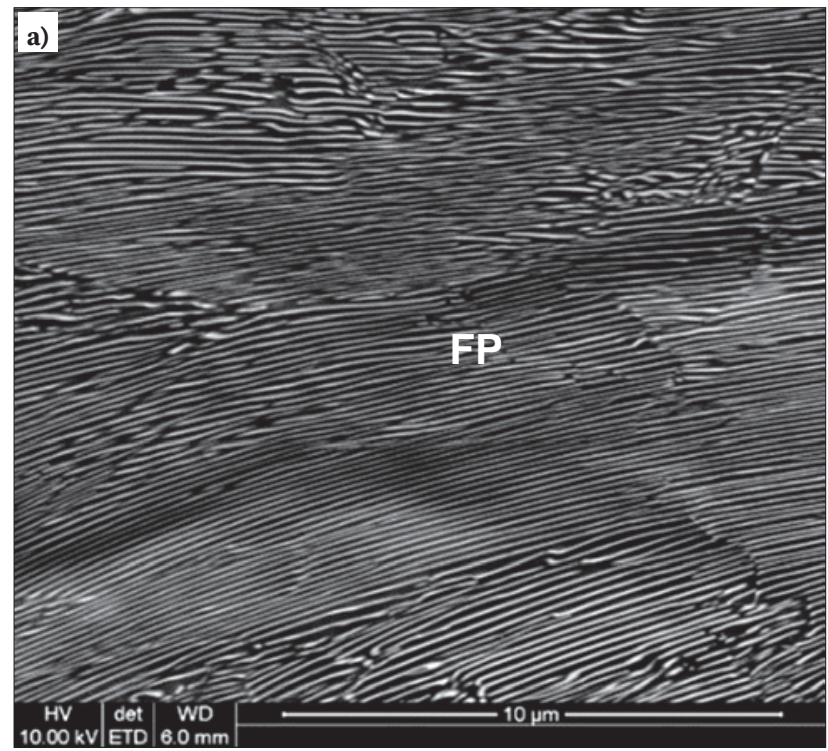

structure is the most deleterious one for the ductility of the high carbon steels.

Therefore, the objective of the numerical modelling was to design cooling sequence which will allow to obtain high and uniform hardness in the rail head and lack of the bainite in the microstructure. Equations in section 3.3 show that the lowest possible average temperature of the pearlitic transformation $\left(T_{\mathrm{p}}\right)$ will result in high hardness. This temperature is calculated from equation (9). Developed software allows to analyse all parameters in the five arbitrarily selected points at the cross section of the rail head but the following three points were considered in the present work: point A located $2 \mathrm{~mm}$ below the surface, point B located $6 \mathrm{~mm}$ below the surface and point $\mathrm{C}$ located in the centre of the rail head. Having the above comments in mind, the following objective function was proposed:

$$
\Phi=\sqrt{w_{\mathrm{S}} S_{0}+w_{\mathrm{b}} S_{\mathrm{b}}+w_{\mathrm{rVV}} \sum_{i=1}^{N e l}\left(\frac{H V_{\mathrm{i}}-H V_{\mathrm{av}}}{H V_{\mathrm{av}}}\right)}
$$

where:

$S_{0}, F_{\mathrm{b}}$-interlamellar spacing and volume fraction of bainite at the location $\mathrm{A}$,

$H V_{\mathrm{i}}$ - hardness in the element $i$ of the FE mesh, $H V_{\text {av }}$ - average hardness at the rail head

$\mathrm{Nel}$ - number of elements at the rail head cross section

$w_{\mathrm{S}}, w_{b}, w_{\mathrm{HV}}$ - weights.

Parameters of the cooling process were the design variables. Optimal cooling parameters were determined using PSO method and the results are presented in next section

\subsection{RESULTS OF THE NUMERICAL SIMULATIONS}

Cooling of the rail $60 \mathrm{E} 1$ was considered. The objective of the numerical modelling was to design cooling process, which gives the minimum of the objective function (15). Two possible cooling strategies were considered distinguished by the number of the immersions in the polymer solution. The heat transfer coefficient (HTC) between the rail head and the solution was determined by the inverse analysis for the temperature measurements. The HTC

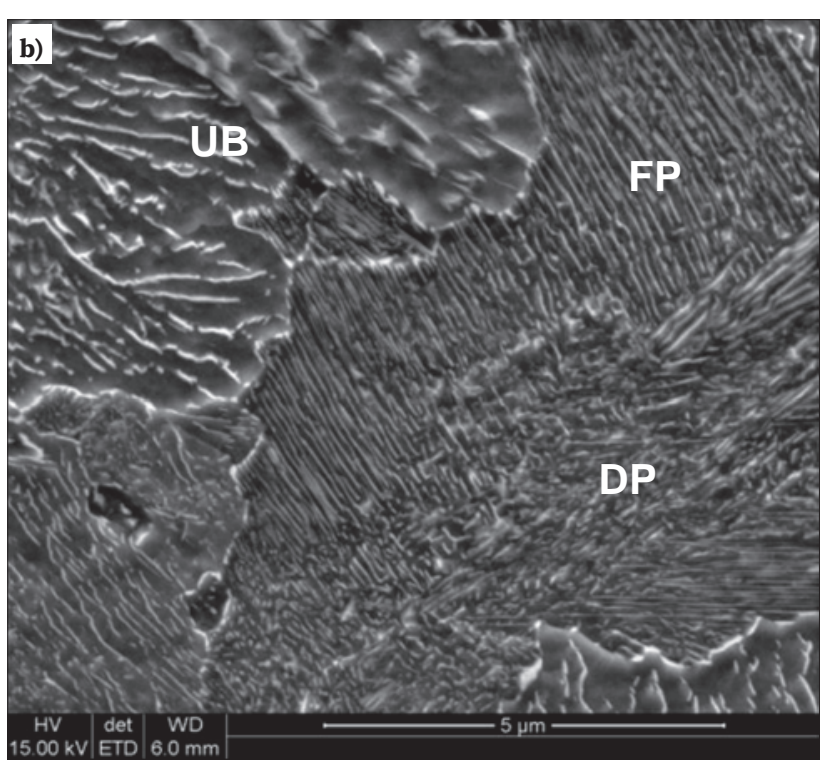

Fig. 5. Microstructure of the R260 steel after transformation: a) at $550^{\circ} \mathrm{C}$; b) at $500^{\circ} \mathrm{C}$. SEM. FP - fine pearlite; DP - degenerated pearlite; UB - upper bainite

Rys. 5. Mikrostruktura stali R260 po przemianie w temperaturach: a) $550^{\circ} \mathrm{C}$; b) $500^{\circ} \mathrm{C}$. SEM. FP - drobny perlit, DP - perlit zdegenerowany; UB - bainit górny 
for the basic concentration of the polymer (8\%) was 1200 $\mathrm{W} /\left(\mathrm{m}^{2} \cdot \mathrm{K}\right)$ for the temperature above $700^{\circ} \mathrm{C}$ and it increased to the maximum value of $1900 \mathrm{~W} /\left(\mathrm{m}^{2} \cdot \mathrm{K}\right)$ when the temperature dropped below $300^{\circ} \mathrm{C}$. Further decrease of the temperature caused decrease on the HTC.

The first strategy assumed cooling from the temperature $1050^{\circ} \mathrm{C}$ (in the centre of the rail head) with five immersions in the solution. Optimal cooling cycle for this strategy is given in Table 2 and calculated time-temperature profiles for the three selected points are shown in Figure 6a. Kinetics of the pearlitic transformation is shown in Figure 6b,c,d. It is seen that almost purely pearlitic microstructure was obtained. Only a small amount of the bainite around $2 \%$ was predicted in the surface area. The calculated average pearlite transformation temperature, $T_{p}$, was $553^{\circ} \mathrm{C}$.

The second strategy assumed cooling from the temperature $1050^{\circ} \mathrm{C}$ with seven immersions in the solution. Optimal cooling cycle for this strategy is given in Table 3 and calculated time-temperature profiles for the three selected points are shown in Figure 7a. Kinetics of the pearlitic transformation is shown in Figure $7 b, c, d$. It is seen that purely pearlitic microstructure was obtained in the whole rail head. On the other hand, the average temperature of transformation was slightly higher than in the first variant, but its influence on the properties was negligible. The calculated average pearlite transformation temperature, $T_{\mathrm{p}}$, was $565^{\circ} \mathrm{C}$.

Table 2. Times of immersion in the solution (S) and cooling in the air (A) for the first variant of cooling

Tabela 2. Czasy zanurzenia w roztworze (S) i chłodzenia w powietrzu (A) dla pierwszego wariantu chłodzenia

\begin{tabular}{|c|c|c|c|c|c|c|c|c|}
\hline $\mathbf{A}$ & $\mathbf{S}$ & $\mathbf{A}$ & $\mathbf{S}$ & $\mathbf{A}$ & $\mathbf{S}$ & $\mathbf{A}$ & $\mathbf{S}$ & $\mathbf{A}$ \\
\hline $60 \mathrm{~s}$ & $8 \mathrm{~s}$ & $15 \mathrm{~s}$ & $8 \mathrm{~s}$ & $30 \mathrm{~s}$ & $23 \mathrm{~s}$ & $15 \mathrm{~s}$ & $6 \mathrm{~s}$ & $15 \mathrm{~s}$ \\
\hline
\end{tabular}

Table 3. Times of immersion in the solution (S) and cooling in the air (A) for the second variant of cooling Tabela 3. Czasy zanurzenia w roztworze (S) i chłodzenia w powietrzu (A) dla drugiego wariantu chłodzenia

\begin{tabular}{|c|c|c|c|c|c|c|c|c|c|c|c|c|c|}
\hline $\mathbf{A}$ & S & $\mathbf{A}$ & S & $\mathbf{A}$ & $\mathbf{S}$ & $\mathbf{A}$ & S & A & S & $\mathbf{A}$ & S & $\mathbf{A}$ & S \\
\hline $140 \mathrm{~s}$ & $8 \mathrm{~s}$ & $25 \mathrm{~s}$ & $18 \mathrm{~s}$ & $15 \mathrm{~s}$ & $8 \mathrm{~s}$ & $15 \mathrm{~s}$ & $5 \mathrm{~s}$ & $15 \mathrm{~s}$ & $4 \mathrm{~s}$ & $15 \mathrm{~s}$ & $3 \mathrm{~s}$ & $15 \mathrm{~s}$ & $3 \mathrm{~s}$ \\
\hline
\end{tabular}

a)

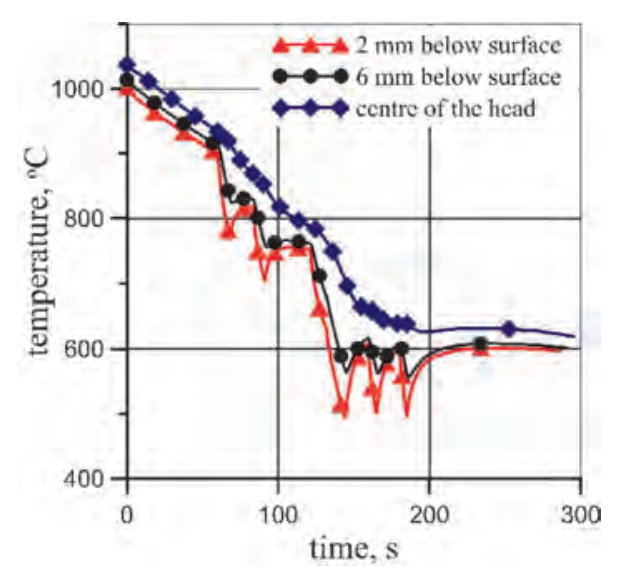

c)

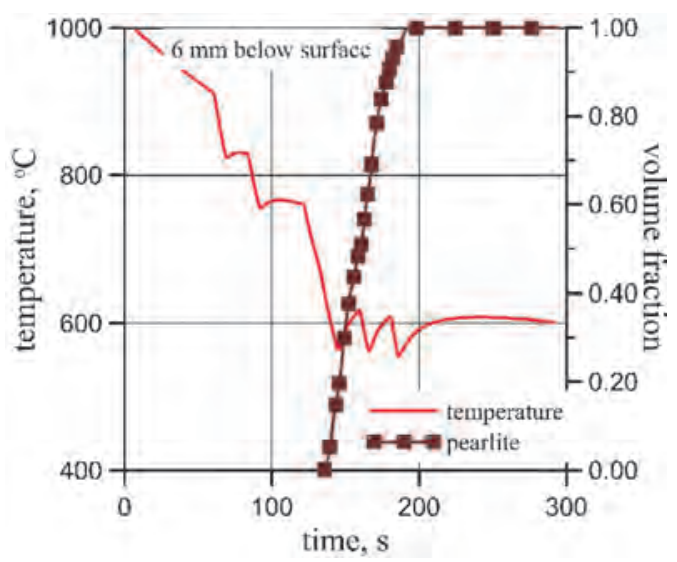

b)

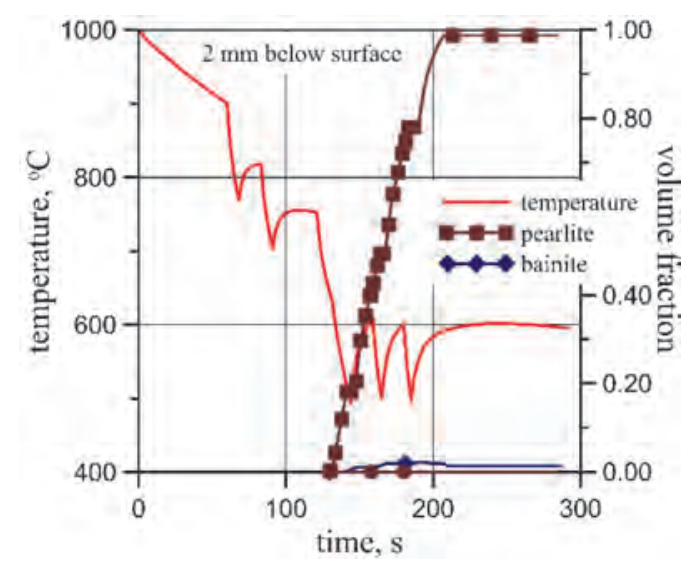

d)

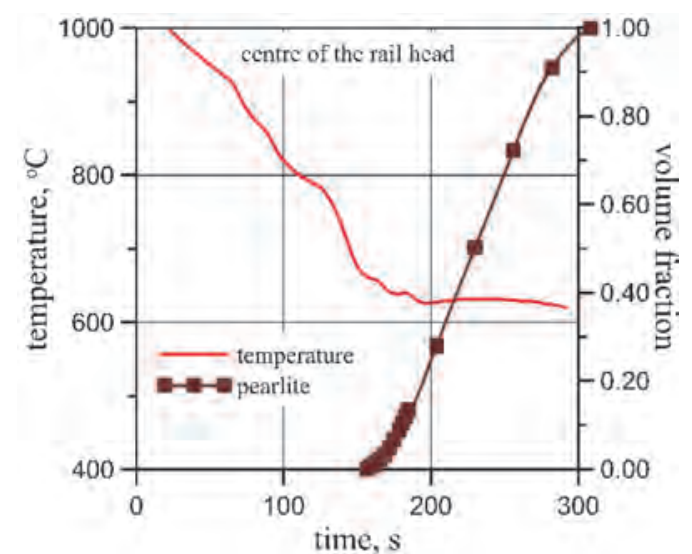

Fig. 6. Optimal variant 1: time-temperature profiles (a) and kinetics of the pearlitic transformation calculated for the points A (b), B (c) and C (d)

Rys. 6. Optymalny wariant 1: zmiany temperatury w funkcji czasu - (a) oraz kinetyka przemiany perlitycznej obliczone dla punktów A (b), B (c) i C (d) 
a)

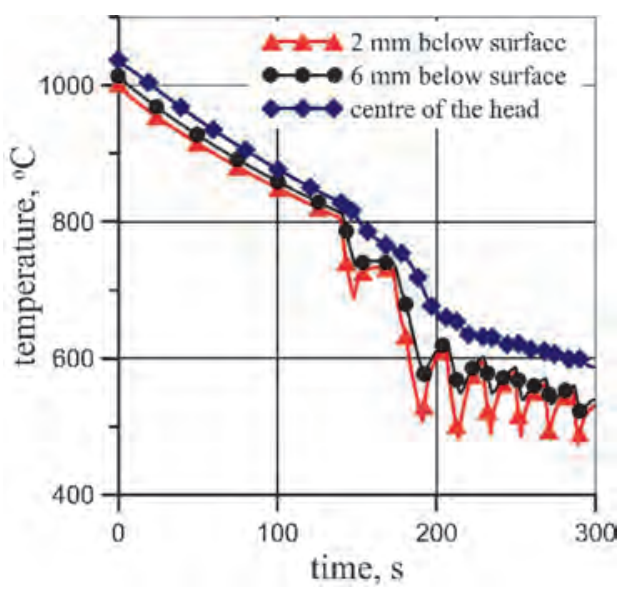

c)

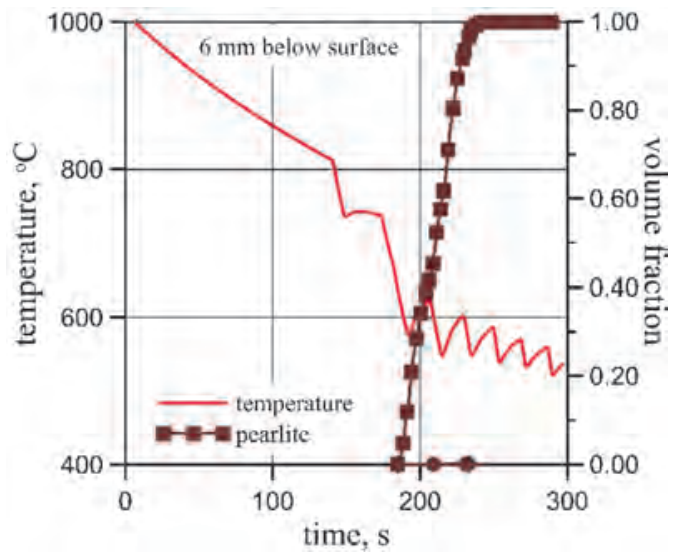

b)

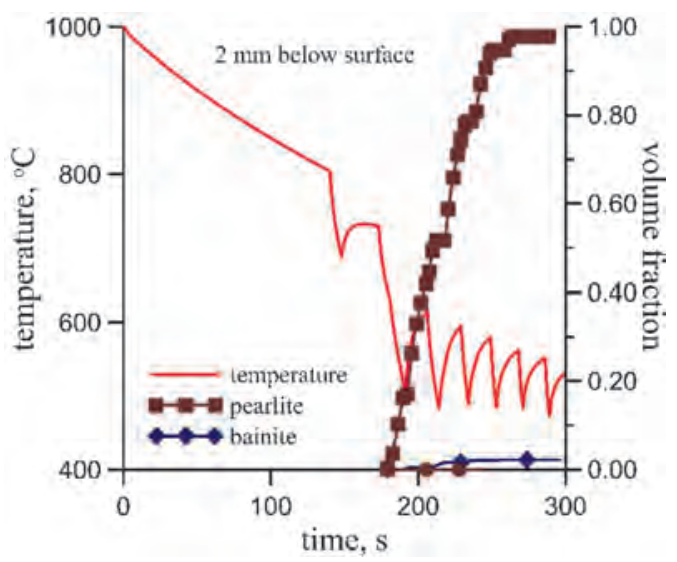

d)

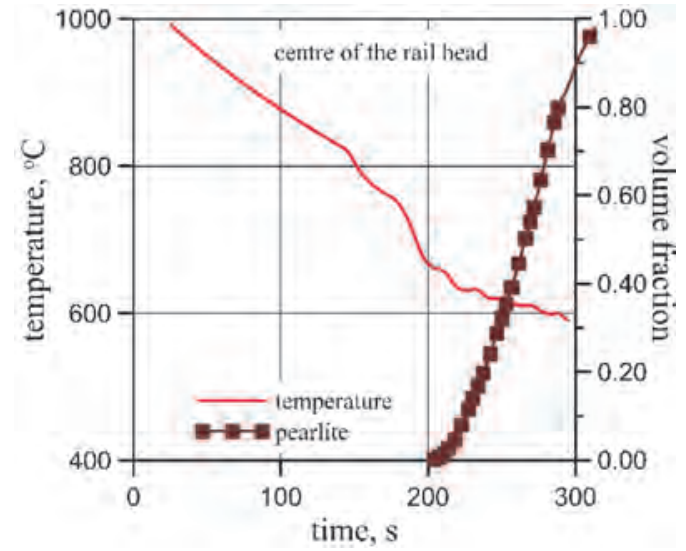

Fig. 7. Optimal variant 2: time-temperature profiles (a) and kinetics of the pearlitic transformation calculated for the points A (b), B (c) and C (d) Rys. 7. Optymalny wariant 2: zmiany temperatury w funkcji czasu - (a) oraz kinetyka przemiany perlitycznej obliczone dla punktów A (b), B (c) i C (d)

\section{RESULTS OF THE HEAD HARDENING EXPERIMENTS}

The 60E1 rail's head were subject to the controlled - accelerated cooling according to cooling cycles described in Table 2 and Table 3. Following the experiments, the cylin-

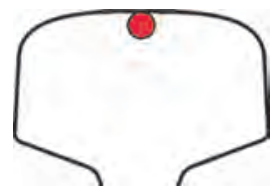

Fig. 8. Location of the sample for tensile test Rys. 8. Miejsce pobrania próbek do statycznej próby wytrzymałościowej
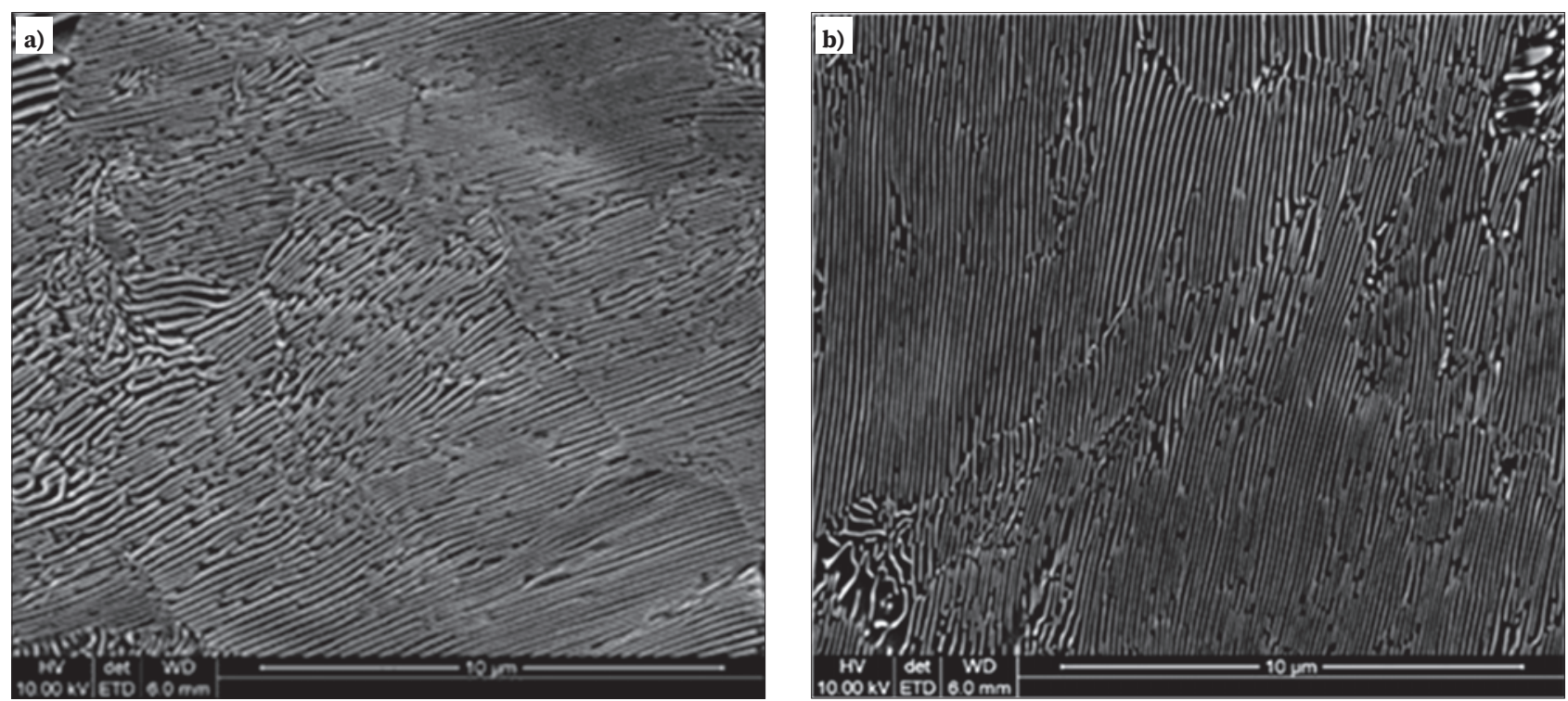

Fig. 9. Pearlite structure at the depth of $5 \mathrm{~mm}$ below the head's running surface: a) after variant 1 ; b) after variant 2 of cooling. SEM Rys. 9. Struktura perlitu w odległości $5 \mathrm{~mm}$ od powierzchni tocznej: a) wariant 1; b) wariant 2. SEM 
Table 4. Mechanical properties of the samples located as in Figure 8

Tabela 4. Właściwości mechaniczne próbek pobranych zgodnie z rysunkiem 8

\begin{tabular}{|c|c|c|c|c|c|}
\hline Variant of cooling & $\boldsymbol{S}_{\mathbf{0}},[\mu \mathrm{m}]$ & $\boldsymbol{R}_{\mathrm{p} 0.2,},[\mathrm{MPa}]$ & $\boldsymbol{R}_{\mathbf{m}},[\mathrm{MPa}]$ & $\boldsymbol{A}_{\mathbf{5}},[\%]$ & $\mathbf{Z},[\%]$ \\
\hline 1 & 0.098 & 885 & 1189 & 12.5 & 24 \\
\hline 2 & 0.102 & 872 & 1175 & 11.9 & 23 \\
\hline
\end{tabular}

drical samples having diameter $\varnothing 12 \mathrm{~mm}$ were machined. The location of the samples is indicated in Figure 8. The microstructure in the area located approximately $5 \mathrm{~mm}$ below the running surface is shown in Figure 9.

Results of the mechanical properties measurement are given in Table 4. It is noteworthy that the samples exhibited very good elongation to fracture values while maintaining a reasonable strength level.

\section{CONCLUSIONS}

The following conclusions were drawn:

- The developed phase transformation model allowed precisely predict the kinetics of pearlite transformation under varying cooling conditions.
- Considering the effect of transformation temperature on the mechanical properties, the method of obtaining high strength combined with good ductility of the running surface of the rail head subject to head hardening was proposed. The method is based on maintaining the mean pearlite transformation temperature $\left(T_{\mathrm{p}}\right)$ during the cyclic cooling close to the temperature at which the elongation to fracture achieves the defined level.

- The approach presented in this paper was patented [21].

\section{Acknowledgements \\ The modelling part of the investigation was financed by the $A G H$ research subsidy.}

\section{REFERENCES}

[1] E. Osto, F. Pegorin, L.E. Giacomini. World's first application of new rail hardening technology and state-of-the art water cooling processes for long rolling. In: Technical contribution to the 52nd Seminário de Laminação - Processos e Produtos Laminados e Revestidos, part of the ABM Week, Rio de Janeiro, 2015, p. 76-88.

[2] R. Kuziak, T. Zygmunt. A new method of rail head hardening of standard-gauge rails for improved wear and damage resistance. Steel Research Int., 2013, 84, p. 13-19.

[3] S.S. Satyam, M. Goutam, G.E. Totten. Overview of pearlitic rails steel: accelerated cooling, quenching, microstructure, and mechanical properties. Journal of ASTM International, 2009, 6 (7), p. 1-26.

[4] R. Kuziak, V. Pidvysots'kyy, M. Pernach, Ł. Rauch, T. Zygmunt, M. Pietrzyk. Selection of the best phase transformation model for optimization of manufacturing processes of pearlitic steel rails. Archives of Civil and Mechanical Engineering, 2019, 19, p. 535-546.

[5] R.J. Ackert, M.A. Nott. Accelerated water cooling of railway rails in-line with the hot rolling mill. Proc. Symp. Accelerated Cooling of Roled Steels, Eds. Ruddle, G.E., Crawley, A.F. Winnipeg: Pergamon Press, 1987, p. 359-372.

[6] S.S. Sahay, G. Mohapatra, G.E. Totten. Overview of pearlitic rail steels: accelerated cooling, quenching, microstructure and mechanical properties. Journal of ASTM International, 2009, 6, p. 1-26.

[7] Fata R.G., Jones J.A., Perlman A.B., Orringer O., A numerical model for estimation of temperature-time history and residual stress in head-hardened rails, Proc. 39th Mechanical Working and Steel Processing Conference, Vol. XXXV, Warrendale, 1998, p. 10371044.

[8] R.D. Morales, G. Lopez, M. Olivares. Heat transfer analysis during water spray cooling of steel rods. ISIJ International, 1990, 30, p. $48-57$.

[9] G. Li, Z. Liu, L. Chen, X. Hou. Numerical calculation of the comprehensive heat transfer coefficient on the surface of rail in the spray cooling process. Journal of Metallurgical Engineering, 2015, 4, p. 13-17.

[10] A. Milenin, M. Pernach, Ł. Rauch, R. Kuziak, T. Zygmunt, M. Pietrzyk. Modelling and optimization of the manufacturing chain for rails. Procedia Engineering, 2017, 207, p. 2101-2106.
[11] A. Milenin, W. Zalecki, M. Pernach, Ł. Rauch, R. Kuziak, T. Zygmunt, M. Pietrzyk. Modelling and optimization of the manufacturing chain for pearlitic and bainitic steel rails. Archives of Civil and Mechanical Engineering, 2020, 20, doi.org/10.1007/s43452-02000107-0.

[12] J.H. Lienhard IV, J.H. Lienhard V. Heat transfer text book. 3rd Ed. Cambridge, 2001.

[13] M. Pietrzyk. Finite element simulation of large plastic deformation. Journal of Materials Processing Technology, 2000, 106, p. 223229.

[14] M. Pietrzyk, R. Kuziak. Modelling phase transformations in steel. In: Microstructure evolution in metal forming processes, (eds), Lin J., Balint D., Pietrzyk M. Oxford: Woodhead Publishing, 2012, p. 145179.

[15] M. Pietrzyk, R. Kuziak. Numerical simulation of controlled cooling of rails as a tool for optimal design of this process. Computer Methods in Materials Science, 2012, 12 (4), p. 233-243.

[16] M. Pietrzyk, Ł. Madej, Ł. Rauch, D. Szeliga. Computational Materials Engineering: Achieving high accuracy and efficiency in metals processing simulations. Amsterdam: Elsevier, 2015.

[17] R. Kuziak, R. Molenda, A. Wrożyna, J. Kusiak, M. Pietrzyk. Experimental verification and validation of the phase transformation model used for optimization of heat treatment of rails. Computer Methods in Materials Science, 2014, 14 (1), p. 53-63.

[18] D. Szeliga, R. Kuziak, T. Zygmunt, J. Kusiak, M. Pietrzyk. Selection of parameters of the heat treatment thermal cycle for rails with respect to the wear resistance. Steel Research International, 2014, 85, p. 1070-1082.

[19] R. Kuziak, V. Pidvysots'kyy, K. Radwański, A. Mazur, T. Zygmunt, M. Pietrzyk, Ł. Rauch, D. Bachniak. Optimization of the heat treatment process to obtain the required distribution of mechanical properties in the rail head of pearlitic rails. Journal of Metallic Materials, 2019, 71 (1), p. 1-7.

[20] R. Kuziak, Y.-W. Cheng, M. Głowacki, M. Pietrzyk. Modelling of the microstructure and mechanical properties of steels during thermomechanical processing. NIST Technical Note 1393, Boulder, 1997.

[21] Sposób obróbki cieplnej warstwy tocznej główki szyny ze stali perlitycznej, zgłoszenie patentowe P430155, 2020 (in Polish). 